The Turkish Online Journal of Design, Art and Communication - TOJDAC

ISSN: 2146-5193, September 2018 Special Edition, p.998-1006

\title{
FORMING THE CREATIVE POTENTIAL OF A CANDIDATE POOL IN HIGHER EDUCATION INSTITUTIONS
}

\author{
Mikhail V. VINICHENKO \\ Russian State Social University, Russia \\ Andrey V. KIRILLOV \\ Russian State Social University, Russia \\ Alexander V. MELNICHUK \\ Russian State Social University, Russia \\ Oksana M. OLEKSYUK \\ Intercomp, Russia \\ Oxana L. CHULANOVA \\ Surgut State University, Russia
}

\begin{abstract}
This article aims to develop methods for improving the creative potential of students as members of a candidate pool. Such research is conducted for the first time since the existing studies focus on methods and techniques for developing creativity without a systematic approach to the development of student's activity and time management. The paper utilizes a coherent two-stage approach with two pedagogical experiments and the subsequent evaluation of their results through a sociological survey. The study was conducted in 2008-2018 and involved 547 students. As a result, the authors have managed to reveal effective methods for activating the creativity of students in higher education institutions, which allowed developing a technology for improving students' creative potential. The above-mentioned methods include the improvement of personal time management with the student's individual development plan; a game-based method of conducting seminars with students divided into two opposing teams and an expert group; the creation of video projects based on their educational program specialization. These methods make students more self-sufficient in the creation of innovative models aimed at the activation and development of their creativity. The novelty of this technology lies in an educator's integrated effect on the student at all educational stages in order to develop the student's creativity, ability to efficiently manage time and perform a constant search for innovative solutions in the course of future work activities.
\end{abstract}

\section{Keywords: Candidate Pool, Creativity, Development, Students, Time Management}

\section{INTRODUCTION}

The competitiveness of modern organizations mostly depends on the ability of their personnel to create innovative products and services. To attain this end, employees should be able to think outside the box, perform their duties in a creative manner and constantly search for new solutions to emerging problems. It is crucial to develop creative potential at all stages of professional training, especially when prospective employees (potential candidates) are added to a candidate pool. Competent HR managers fill their personnel reserves with students from different higher education institutions. They try to detect the most talented and creative young people while they are still studying. Despite the constant improvement of educational standards, higher education institutions are not actively and efficiently developing students' creative potential, their time and life management.

This problem is the research subject of many scholars and practitioners around the world. Freund A.M., Baltes P.B. and Greenglass E.R. were the first to study life management (Freund \& Baltes, 1998, 2002; Greenglass, 2002).

Such American scientists as Moore, Kimberly A. and Pearson, Brian J. supposed that professional skills, creativity and time management should be developed through regular online tasks built over some concept, problem-based situations and generalized experiment results (Moore \& Pearson, 2017). 
Chinese scientist Zhang Wenxiao addressed the issue of increasing a student's independence by determining their own development path. Many studies showed that students' choices often depend on the authority of their teachers and (or) fellow students (Zhang, 2017). A student's self-sufficiency in the context of time management was thoroughly considered by the following American scientists: Wolters C.A., Won S. and Hussain M. (Wolters, Won \& Hussain, 2017).

Two Turkish scholars, Durak Hatice Yildiz and Saritepeci Mustafa, focused on the complexity of time management for the purpose of solving school tasks and the negative behavior of students using tablets with Internet access (Durak \& Saritepeci, 2017).

Creativity connected with time management draws the attention of many researchers. Thus, German scientists, Alvarez Simone, Nikendei Christoph and Schultz Jobst-Hendrik analyzed the motivation and time management of medical students regardless of the existing standards. As a result, they created an innovative approach used in the transition from theory to practice (Alvarez, Nikendei \& Schultz, 2017).

Some Canadian researchers tried determining an employer's requirements for graduates and focus on the candidate's competitive advantages in time management, teamwork and their creative approach (Chhinzer \& Russo, 2018). Two Canadian scientists, Aeon Brad and Aguinis Herman, demonstrated a systematic and multilevel approach to the study of time management from the sociological, psychological and economic perspectives (Aeon \& Aguinis, 2017). American scholar Forst Kimberly concluded that the ability to properly manage time and prioritize is vital for future athletes and nurses (Forst, 2017).

Romanian scientists Mustata I.C., Alexe C.G. and Alexe C.M., distinguished time management, creativity, flexibility and conflict management among other twenty-one management competencies (Mustata, Alexe \& Alexe, 2017). Their research correlates with the studies of Russian and Slovak scientists in applying innovative technologies to develop the creative potential of young people (Buley et al., 2016, Chulanova et al., 2017).

American scientists studied the effectiveness of group work as exemplified by nursing students. They marked the complexity of time management and disputable confirmation of an equal contribution to the overall result, especially creative innovations, as the main shortcomings of these group activities (Hampton \& El-Mallakh, 2017). Other scholars suggested using the group's potential when making managerial decisions (Wittenbaum et al., 2004).

A significant aspect of developing student's creative potential is the creation of favorable and safe learning conditions in higher education institutions (Rogach et al., 2016, Vinichenko et al., 2016).

Even though there is a quite large number of scientific works concerned with this problem; a fullfledged system of technologies that allow effectively using the creative potential of young people has not been developed yet. Therefore, this study aims to elaborate a technology for improving the creative potential of students.

\section{METHODS}

To determine the modus operandi of methods and techniques increasing the student's activity and developing their creative potential, the authors of the article carried out a sociological study in 2008-2018. This research included two pedagogical experiments and sociological surveys to prepare the most appropriate technology for developing a student's creative potential. The authors chose respondents among the students obtaining a degree in "Personnel Management", "Management", "Document Support of Management", "State and Municipal Management" and "Conflict Resolution Studies" at the Faculty of Management of Russian State Social University (547 respondents in total).

These experiments were aimed at determining the methods for enhancing students' creativity and systematic approach to studying, as well as developing the basic technologies for increasing students' activity and creative potential based on the experiment results. 
According to the scientific hypothesis of the above-mentioned experiments, a highly creative activity, systematic approach and effective time management will better prepare students for solving professional problems.

\section{The first pedagogical experiment}

The first pedagogical experiment entitled "The development of creativity and systematic thinking while preparing and holding practical classes in "Personnel Management" and "HR Management" was conducted in 2008-2009.

The first experiment utilized a game-based technology of conducting seminars. The study group was divided into several subgroups. Throughout the discussion of the training subject, each opposing team asked other participants problem-based questions. The experts selected from the best-trained students evaluated the whole discussion of these opposing teams in conformity with specified factors, including originality and creativity. The teacher also assessed the work of these experts based on their consistency, adherence to principles, ability to see innovations, creativity and prospects for the development of students and subgroups revealed in the course of the discussion.

\section{The second pedagogical experiment}

The second pedagogical experiment entitled "The development of creative potential using modern technologies" was conducted in 2010-2018. It was designed to further develop the students' creative abilities and their systematic thinking with the help of time management, video projects, coaching and individual plans with alternative development options, etc. The experiment consisted of two stages: the first stage was held in 2010-2014, the second one was conducted in 2015-2018.

During the first stage of the experiment, the students improved their creative abilities alongside with developing their skills in preparing and implementing projects related to their field of study. The peculiarity was that the students made a video project for improving the subsystem of personnel management described in their graduate qualification work. Several creative groups formed on a voluntary basis worked on the above-mentioned projects. As a rule, they chose one topic and wrote a script related to this topic. Relying on the works of Atkinson M., Chois R.T., Hackman J.R. and Wageman R., the conductor of the pedagogical experiment used some coaching methods, i.e. the educator observed the work of creative groups and guided them in creating and implementing a set of actions by asking various questions (Atkinson \& Chois, 2012; Hackman \& Wageman. 2005).

Throughout the second stage of the experiment, one of the methods was used to improve the students' time management or the so-called "life management", i.e. the composition and implementation of the students' individual development plans for the period of studying at university and five years after graduation. The students' choice of personal development path became experimental. The first way allowed the students to independently determine their goals, tasks, time and order of actions during training and after graduation. The second way involved the external formation of goals by parents, teachers and organizations.

\section{RESULTS}

\section{Results of the first pedagogical experiment}

The experiment demonstrated that $37 \%$ of the students wanted to enter the expert group. In $93 \%$ of cases, the student groups under consideration were able to combine their efforts to conduct a discussion with the opposing team. In $85 \%$ of cases, spontaneous leaders appeared who organize the group work and manage the discussion with their opposing team. In addition, $64 \%$ of the students were dissatisfied with the evaluation provided by the expert group from the opposing team after the class ended.

To determine the impact on the development of creativity, the authors of the article interviewed the students. The data analysis (Figure 1) showed that $78 \%$ of the respondents approved of this form of class, and only $2 \%$ were against it. 
The Turkish Online Journal of Design, Art and Communication - TOJDAC

ISSN: 2146-5193, September 2018 Special Edition, p.998-1006

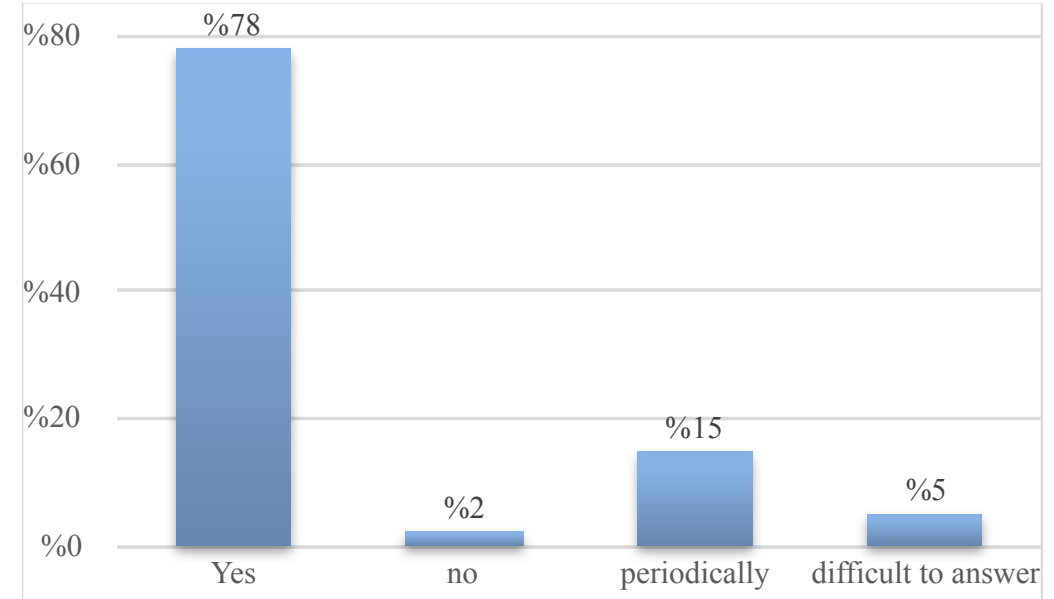

Figure 1. The answers to the question: "Would you like to have such classes held continuously?" Source: own research (2009)

It is worth mentioning that most students improved their creativity (93\%) thanks to this new form of conducting classes and only $1 \%$ of the respondents did not see any changes at all (Figure 2).

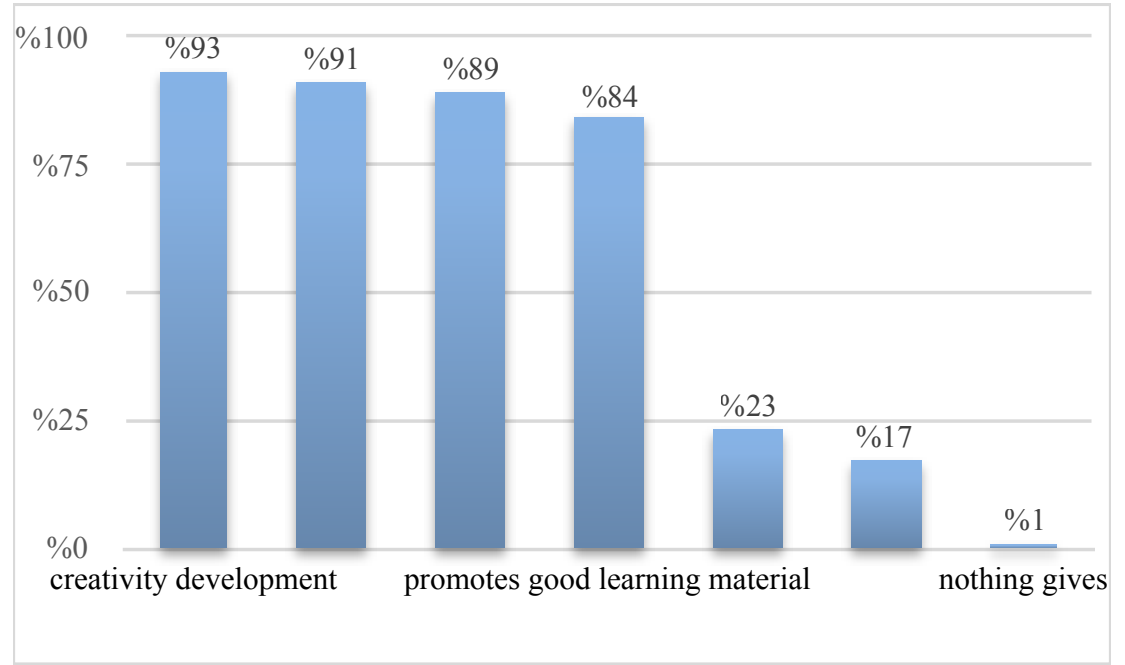

Figure 2. The answers to the question: "What does this form of lessons give you?". Source: own research (2009)

\section{Results of the second experiment}

During the first stage, $87 \%$ of the students participated in the creation of video projects. $75 \%$ of the participants needed some coaching. At the end of this experiment stage, the authors conducted a survey to assess the adequacy of this teaching form. As a result, $83 \%$ of the respondents noted that their work on video projects was quite useful (Figure 3-4). 
The Turkish Online Journal of Design, Art and Communication - TOJDAC

ISSN: 2146-5193, September 2018 Special Edition, p.998-1006

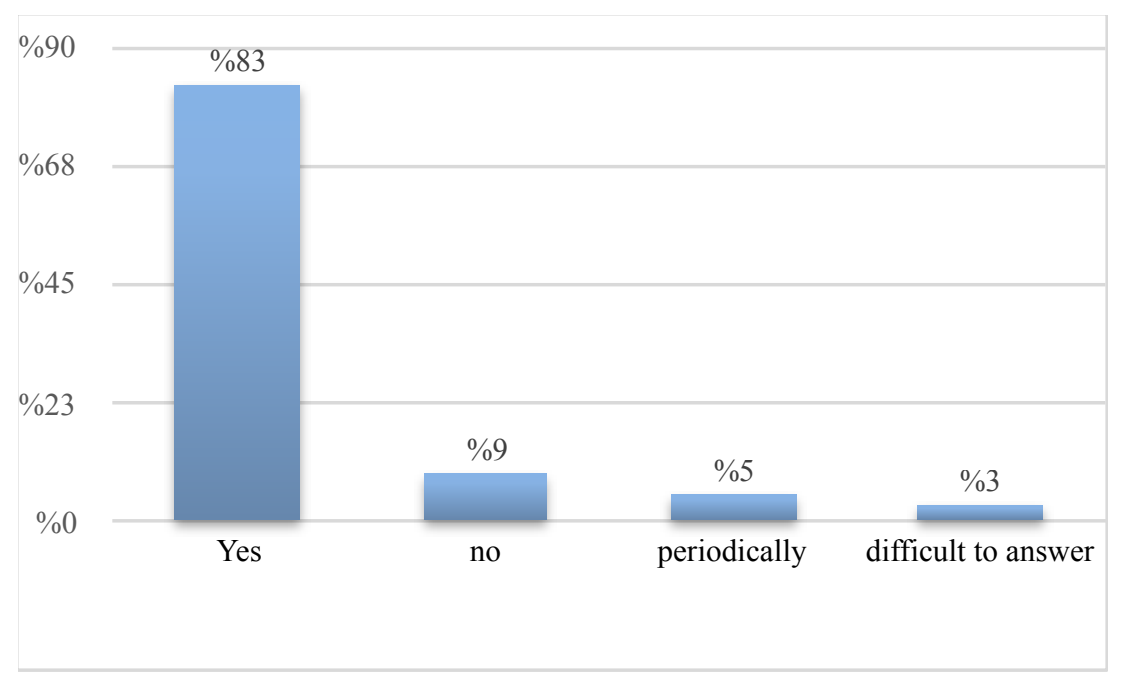

Figure 3. The answers to the question: "Do we need such a form of educational work as the creation of video projects?". Source: own research (2014)

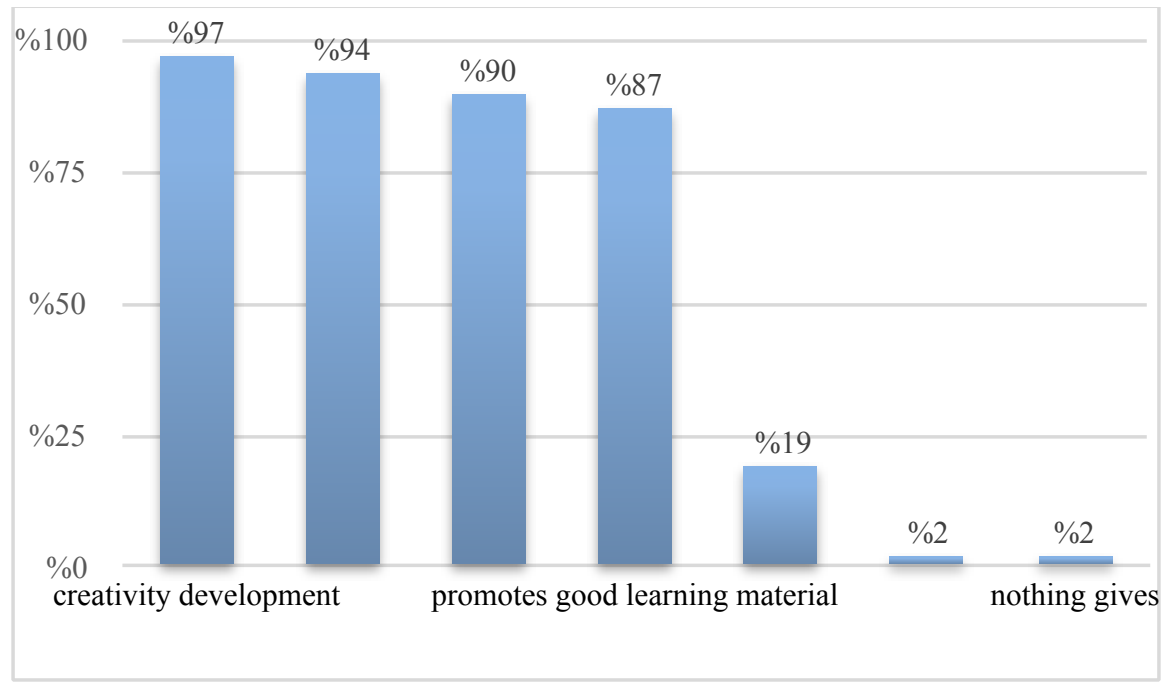

Figure 4. The answers to the question: "What does this form of teaching give you?" Source: own research (2014)

During the second stage, $100 \%$ of the respondents were involved in the development of their individual plans. $37 \%$ of the students instantly liked the idea of managing their own life, created an individual plan and immediately started using it. By the end of the semester, all the students had reported the results of their planned activities. $18 \%$ of the experiment participants really followed their individual plan.

The viability of an individual development plan was emphasized by $72 \%$ of the respondents, with only $10 \%$ of the students noting its negative aspects (Figure 5). 
The Turkish Online Journal of Design, Art and Communication - TOJDAC

ISSN: 2146-5193, September 2018 Special Edition, p.998-1006

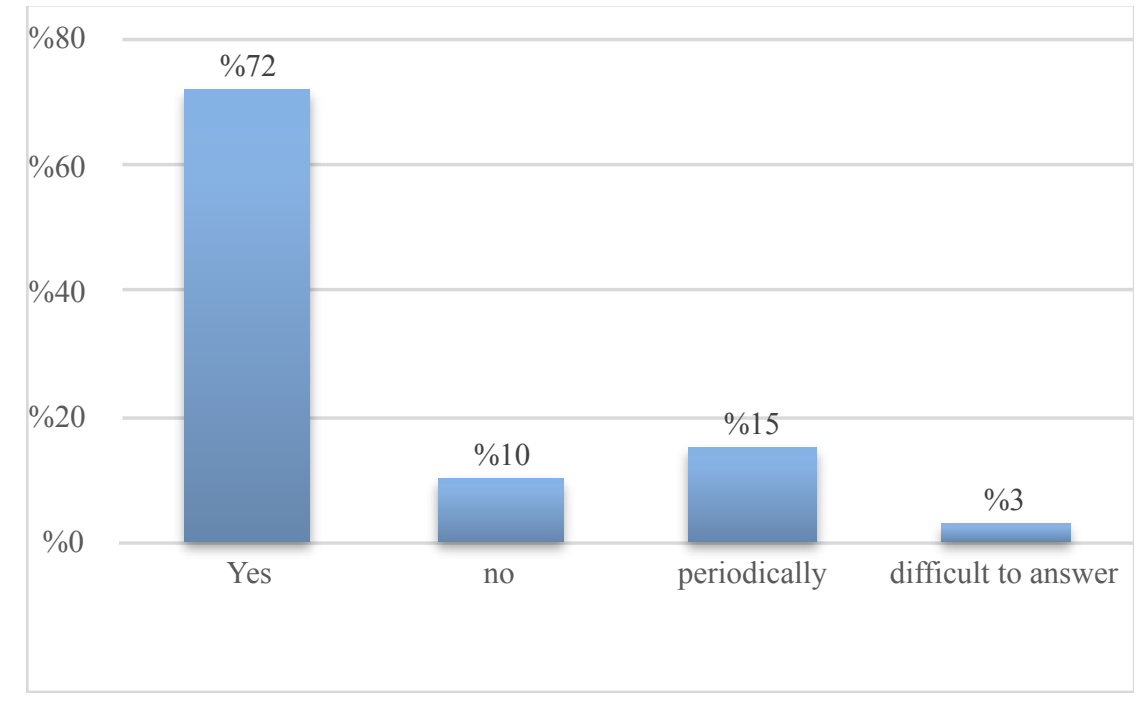

Figure 5. The answers to the question: "Do we need such a form of educational work as the creation of individual development plans?". Source: own research (2018)

According to the students, this form of educational work would intensify the study of the chosen discipline (95\%), heighten their professional interest (90\%) and promote their creativity (87\%) (Figure $6)$.

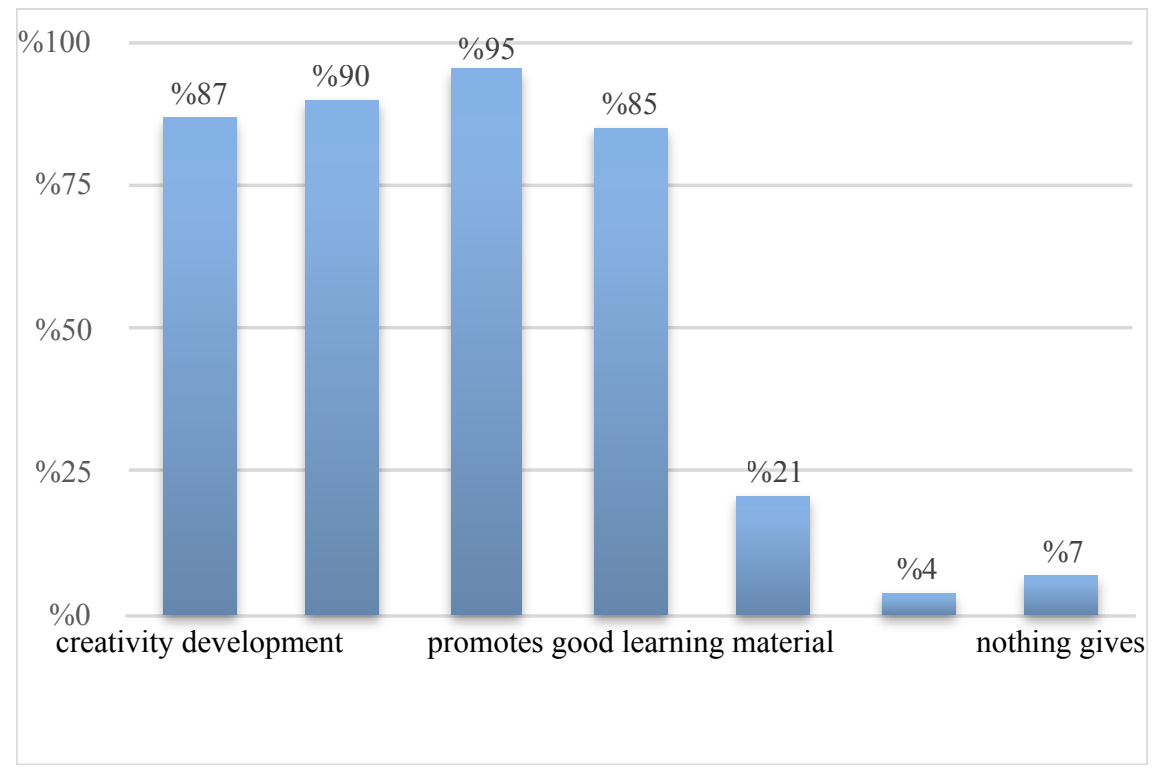

Figure 6. The answers to the question: "What does this form of teaching give you?". Source: own research (2018)

\section{DISCUSSION}

The authors of this article consistently conducted two pedagogical experiments to determine how the methods and techniques increasing the student's activity could further develop their creative potential. During the first experiment, they concluded that the students got interested in a game-based seminar (the division of the study group into two opposing teams and the expert group). The participants demonstrated a high degree of self-organization. The most active students strived to become leaders of their respective collectives or get into the expert group. At the same time, $64 \%$ of the respondents were dissatisfied with the evaluation provided by the selected experts. This situation can be explained by the high status of the experts compared to other students in the study group, their adherence to principles in assessing questions and answers of the opposing groups and unwillingness to see fellow students as the experts (leaders). 
This form of conducting classes developed the students' creativity (93\% of the respondents), increased their activity and interest in employment (a future profession), and helped them to better assimilate new information. In addition, the students developed competitiveness, team spirit, interest in a collective result and responsibility for their actions (the expert group). These results correlate with the studies of the American scientists - Hampton Debra C. and El-Mallakh Peggy (Hampton \& ElMallakh, 2017).

During the first stage of the second pedagogical experiment, the authors managed to increase the students' activity and creativity in obtaining professional competencies through the creation of video projects. Most students $(83 \%)$ noted the viability of this type of educational work to further develop their creative potential. The creation of a specific situation in the video projects to form and improve professional competencies can be associated with the studies conducted by the Romanian scientists Mustata I.C., Alexe C.G. and Alexe C.M. (Mustata, Alexe \& Alexe, 2017). The coaching methods used by the educator during the experiment also contributed to the development of the students' creativity and systematic planning of their lives and learning activities.

While working on their video projects, receiving the expert evaluation and posting their video clips on the university website for the general public, the students' desire for creativity increased significantly (97\%), their professional interest heightened (94\%), the study of the corresponding discipline became more active $(90 \%)$, which contributed to successful mastery of the presented material $(87 \%)$. This method was highly appraised in the development of the students' creativity. In fact, it enabled the students to create their own projects in conformity with the discipline they were studying, develop corresponding scripts, choose and manage their project participants, select a location for the survey and materials to use. The students who prepared the best projects raised their social status and learnt how to win in a profession-related competition. During the last stage of working on their video projects, the students summarized and analyzed the results which correlated with the data of the American scientists Moore, Kimberly A. and Pearson, Brian J. (Moore \& Pearson, 2017).

During the second stage, the authors of the article analyzed the possibility of developing the students' creativity in the framework of improving personal time management. For this purpose, the students compiled individual development plans to prearrange and optimize their life, study and work for the period spent in university and five years after graduation. $100 \%$ of the students took part in the experiment but only $18 \%$ of them used the individual plans for their personal development. This situation is explained by the lack of experience in the systematic planning of their life, the complexity of plan creation and unwillingness to constantly monitor their actions and therefore optimize time management. Nevertheless, $87 \%$ of the respondents thought that individual development plans could further develop their creativity.

A significant achievement of this pedagogical experiment was the acquisition of skills in systematic thinking and the creation of the students' original management system.

In general, these two pedagogical experiments enabled the authors to test several methods of developing and improving the students' creativity. According to the students, the most effective technique was the creation of video projects. Game-based seminars with the division of the study group into two opposing teams and the expert group were ranked second. The improvement of personal time management with the use of an individual development plan became the students' third favorite. Coaching also played a significant role in the experiment.

These methods should form a full-fledged technology for developing students' creativity. The first step is to improve personal time management using students' individual development plan. Despite its complex formation and the constant monitoring of a student's status and actions, this method develops the systematic planning of life and study and improves the creativity of active students. Then it is advisable to use the game-based method of conducting seminars when a study group is divided into two opposing teams and an expert group. This form of conducting classes strengthens creativity, develops leadership qualities and increases self-management of a study group. In conclusion, it is useful to create video projects that solidify students' independence in making innovative models and awaking their creativity. 


\section{CONCLUSION}

The creative potential of employees is among the most important factors in the dynamic development of any organization. Both business representatives and state institutions pay close attention to its revelation and improvement. The most competent managers form a candidate pool from students and look for creative people while they are still studying at university. Teaching staff in higher education institutions also aim to develop the creative potential of students.

The search for new ways to develop students' creative potential in the course of pedagogical experiments revealed effective methods for activating students' creativity in higher education institutions and offered technologies for the further development of their creative potential fulfilling the research objective. This technology has a complex impact on students at all educational stages and enables them to perform a constant search for innovative solutions in the course of future work activities.

The sequence of actions in this technology is determined by a non-standard life model based on time management (students' individual development plans), game-based seminars stirring students' interest in creative activities and innovative video projects that help to work on consistency, creativity and self-sufficiency.

Being partially tested, the above-mentioned methods can bring more prominent results in case of their proper application due to the emergent character of the newly created system.

\section{ACKNOWLEDGMENTS}

The publication was prepared with the financial support of the RFBR, project № 17-03-00059-ОГН.

\section{REFERENCES}

Aeon, B., \& Aguinis, H. (2017). It's about time: new perspectives and insights on time management. Academy of Management Perspectives, 31(4), 309-330. DOI: 10.5465/amp.2016.0166.

Alvarez, S., Nikendei, C., \& Schultz, J.-H. (2017). Development of a didactical training concept for peer tutors in gross anatomy. Anatomical Sciences Education, 10(5), 495-502. DOI: 10.1002/ase. 1691.

Atkinson, M., \& Chois, R. T. (2012). Art \& Science of Coaching: Inner Dynamics. Moscow: Alpina Pablisher.

Buley, N. V., Demchenko, T. S., Makushkin, S. A., Vinichenko, M.V., \& Melnichuk, A.V. (2016). Human resource management in the context of the global economic crisis. International Journal of Economics and Financial Issues, 6(8S), 160-165.

Chhinzer, N., \& Russo, F. M. (2018). An exploration of employer perceptions of graduate student employability. Education and Training, 60(1), 104-120. DOI: 10.1108/ET-06-2016-0111.

Chulanova, O. L., Kucherenko, G. H., Chulanov, D. V., Kirillov, A. V., \& Melnichuk, A. V. (2017). Crowd-Technology in the Selection of Personnel. European Research Studies Journal, XX(4B), 380-397.

Durak, H. Y., \& Saritepeci, M. (2017). Investigating the Effect of Technology Use in Education on Classroom Management within the Scope of the FATiH Project. Cukurova University Faculty of Education Journal, 46(2), 441-457. DOI: 10.14812/cufej.303511.

Forst, K. A. (2017). Motivational factors of student nurse athletes attributing to academic success. Nurse Educator, 42(6), 324-327. DOI: 10.1097/NNE.0000000000000386.

Freund, A. M., \& Baltes, P. B. (1998). Selection, Optimization, and Compensation as Strategies of Life Management: Correlations with Subjective Indicators of Successful Aging. Psychology and Aging, 13(4), 531-543.

Freund, A. M., \& Baltes, P. B. (2002). Life-Management Strategies of Selection, Optimization and Compensation: Measurement by Self-Report and Construct Validity. Journal of Personality and Social Psychology, 82(4), 642-662.

Greenglass, E. R. (2002). Proactive Coping and Quality of Life Management. In Beyond Coping: Meeting Goals, Visions, and Challenges (pp. 37-62). Oxford: Oxford University Press.

Hackman, J. R., \& Wageman, R. (2005). A Theory of Team Coaching. Academy of Management Review, 30(2), 269-287. 
The Turkish Online Journal of Design, Art and Communication - TOJDAC

ISSN: 2146-5193, September 2018 Special Edition, p.998-1006

Hampton, D. C., \& El-Mallakh, P. (2017). Opinions of Online Nursing Students Related to Working in Groups. Journal of Nursing Education, 56(10), 611-616. DOI: 10.3928/01484834-20170918-06.

Moore, K. A., \& Pearson, B. J. (2017). Soft Skills in an Online Class. Horttechnology, 27(5), 583-585. DOI: $10.21273 /$ HORTTECH03672-17.

Mustata, I. C., Alexe, C. G., \& Alexe, C. M. (2017). Developing competencies with the general management in business simulation game. International Journal of Simulation Modelling, 16(3), 412-421. DOI: 10.2507/IJSIMM16(3)4.383.

Rogach, O. V., Frolova, E. V., Kirillov, A. V., Bondaletov, V. V., \& Vinichenko, M. V. (2016). Development of favourable learning environment and labor protection in the context of harmonization of social interaction of educational system objects. IEJME - Mathematics Education, 11(7), 2547-2558.

Vinichenko, M. V., Frolova, E. V., Maloletko, A. N., Bondaletov, V. V., \& Rogach, O. V. (2016). Main directions of creating a favorable learning environment and labor protection in the interest of enhancing health of the personnel and students in education foundation. IEJME - Mathematics Education, 11(5), 1163-1174.

Wittenbaum, G. M., Hollingshead, A. B., Paulus, P. B., Hirokawa, R. Y., Ancona, D. G., Peterson, R. S., Jehn, K. A., \& Yoon, K. (2004). The Functional Perspective as a Lens for Understanding Groups. Small Group Research, 35(1), 17-43.

Wolters, C. A., Won, S., \& Hussain, M. (2017). Examining the relations of time management and procrastination within a model of self-regulated learning. Metacognition and Learning, 12(3), 381-399. DOI: 10.1007/s11409-017-9174-1.

Zhang, W. (2017). Using Classroom Assessment to Promote Self-Regulated Learning and the Factors Influencing Its (In)Effectiveness. Frontiers of Education in China, 12(2), 261-295. DOI: 10.1007/ s11516-017-0019-0. 